\title{
MODERN IMPLEMENTATION OF THE CONCEPT OF SPIRITUAL AND MORAL EDUCATION OF STUDENT YOUTH (ON THE EXAMPLE OF THE DAGESTAN STATE PEDAGOGICAL UNIVERSITY)
}

\author{
(C) Maida G. Mustafaeva, Farid M. Mustafaev, Sarat G. Hiyasova \\ Dagestan State Pedagogical University, \\ Makhachkala, The Republic of Dagestan, Russian Federation \\ sara.khiasova@gmail.com
}

The subject of consideration is the emerging practice of participation of public institutions in the spiritual and moral education of students and schoolchildren, and within its framework, the practice of statereligious partnership. The formed model of activity "university-school-social partnership" is analyzed. The process of forming a system of state-religious partnership in the spiritual and moral education of students is considered in more detail, carried out in the educational and pedagogical process by the teaching staff of the oldest in the North Caucasus Dagestan State Pedagogical University. Almost all faculties of the pedagogical university conduct disciplines - religious studies, the history of world religions. It is emphasized that the training of students in this direction is necessary for a modern specialist. On the basis of questionnaires, it was concluded that university students study with interest the peculiarities of the religions of Dagestan as a multinational and polydenominational region of the Russian Federation, there is a growing interest in Muslim law and religious disciplines in general. This interest is explained not only by the recognition of the serious contribution of Muslim lawyers to the world legal culture, but also by the role that Islam plays in the modern world, which has a direct impact on the political situation in many countries and the system of international relations in general.

Key words: state, schoolchildren, students, spiritual and moral education, clergy, denomination, social partnership.

\section{[М.Г. Мустафаева, Ф.М. Мустафаев, С.Г. Хиясова Современная реализация концепции духов- но-нравственного образования студенческой молодежи (на примере Дагестанского государ- ственного педагогического университета)]}

Предметом рассмотрения является складывающаяся практика участия общественных институтов в духовно-нравственном образовании студентов и школьников, и в ее рамках практика государственно-религиозного партнерства. Анализируется сформировавшаяся модель деятельности «вузшкола-социальное партнерство». Более подробно рассматривается процесс формирования системы государственно-религиозного партнерства в духовно-нравственном образовании студентов, осуществляемый в учебно-педагогическом процессе профессорско-педагогическим коллективом старейшего на Северном Кавказе Дагестанского государственного педагогического университета. Почти на всех фракультетах педагогического вуза ведутся дисциплины - религиоведение, история мировых религий. Подчёркивается, что подготовка студентов в данном направлении является необходимой для современного специалиста. На основании анкетных опросов, сделан вывод, что студенты вуза с интересом изучают особенности религий Дагестана как полинационального и поликонфессионального региона РФ, растет интерес к мусульманскому праву, религиоведческим дисциплинам в целом. Такой интерес объясняется не только признанием серьезного вклада мусульманских юристов в мировую правовую культуру, сколько той ролью, которую в современном мире играет ислам, оказывающий прямое влияние на политическую ситуацию во многих странах и систему международных отношений в целом.

Ключевые слова: государство, школьники, студенты, духовно-нравственное воспитание, духовенство, конфессия, социальное партнерство.

Maida G. Mustafaeva - Ph.D. (Advanced Doctorate) in Philosophy, Professor, Dagestan State Pedagogical University, Makhachkala, The Republic of Dagestan, Russian Federation.

Farid M. Mustafaev - Ph.D. (Advanced Doctorate) in Philosophy, Professor, Synergy University, Moscow, Russian Federation. 
Sarat G. Hiyasova - Ph.D. in Pedagogy, Associate Professor, Dagestan State Pedagogical University, Makhachkala, The Republic of Dagestan, Russian Federation.

Мустафраева Маида Ганифраевна - доктор фрилософрских наук, профессор, Дагестанский государственный педагогический университет, г. Махачкала, Республика Дагестан, Российская Федерация.

Мустафраев Фарид Мустафраевич - доктор философркких наук, профрессор, Университет «Синергия». г. Москва, Российская Федерация, Российская Федерация.

Хиясова Сарат Гасановна - кандидат педагогических наук, доцент, Дагестанский государственный педагогический университет, г. Махачкала, Республика Дагестан, Российская Федерация.

Since 2009, in a number of regions, and since 2012 in all constituent entities of Russia, a new subject area of educational orientation "Foundations of the spiritual and moral culture of the peoples of Russia" has been introduced in the general education school. Later this name was changed in elementary school to "Fundamentals of Religious Cultures and Secular Ethics" (FRCSE). This is the name of a comprehensive training course, which includes six training modules, one of which is studied at the choice of the student's family, four modules on religious cultures (Orthodox Christianity, Islam, Buddhism, Judaism) and two alternative modules on secular (civic) ethics and religious studies. In fact, we are talking about the restoration in the modern Russian school of the traditional religious and moral education of children at the choice of their family.

By the mid-2000s, approximately $5-8 \%$ of schoolchildren had already studied such subjects and courses in different classes [9 p. 3]. The subject area of the FRCSE is currently included in the compulsory part of the curriculum in a minimal, actually experimental format, in the $4^{\text {th }}$ grade ( 1 hour per week, 34 hours in total) in schools of the Republic of Dagestan. Nevertheless, despite the minimized and in some respects distorted format of teaching ("complex course" instead of a group of subjects), this already forms a new social and pedagogical reality for our education system and society as a whole.

The novelty lies mainly in two features. The first is the direct participation of parents and families in the choice of an educational discipline of an ideological educational orientation for their child, the teaching of which in a general education school is guaranteed by the state. The second is the participation of religious organizations (denominations) in the teaching of relevant academic disciplines on religious cultures, in the spiritual and moral education of schoolchildren, which is the purpose of this teaching.

At the same time, we would like to note that in the conditions of a multi-national and poly- denominational region, that is the Republic of Dagestan with its polyjuridism in family and household relations, this problem acquires a certain significance and specificity.

The subject of our consideration is the emerging practice of participation of public institutions in the spiritual and moral education of students and schoolchildren and, within its framework, the practice of state-religious partnership. Spiritual and moral education is understood here as the study by schoolchildren (at the choice of parents or legal representatives) of traditional religious culture and their upbringing, the formation of a value-semantic sphere and moral attitudes. At the same time, it is clear that the practice in question is an integral part of the integral educational process at school.

The subject of our consideration is the emerging practice of participation of public institutions in the spiritual and moral education of students and schoolchildren and, within its framework, the practice of state-religious partnership. Spiritual and moral education is understood here as the study by pupils (at the choice of parents or legal representatives) of traditional religious culture and their upbringing, the formation of a value-semantic sphere 
and moral attitudes. At the same time, it is clear that the practice in question is an integral part of the holistic educational process at school.

A qualitatively new condition of state-religious partnership in spiritual and moral education with the introduction of the FRCSE became the fact that the teaching of religious culture in state and municipal educational organizations is now the sphere of joint competence of the state and the relevant denominations. This situation is gradually emerging in our education system as the teaching of religious cultures expands in the regions; it has already become the subject of scientific and pedagogical research [8, p.6].

Until 2009, the participation of denominations in the spiritual and moral education of schoolchildren was regulated at the regional level. The federal level was represented only by the information and methodological material of the Ministry of Education and Science of the Russian Federation with an approximate agreement on cooperation between the educational administration of the constituent entity of the Russian Federation and the Russian Orthodox Church. In this rough agreement, the main directions of interaction between the state executive body in the field of education and the religious organization were fixed, which can be enshrined in agreements, cooperation treaty concluded in the regions. Its development and publication contributed to the streamlining of state-religious agreements in this area in the constituent entities of the Russian Federation and their development in general. The letter also noted that "such agreements can be concluded with centralized religious organizations of other religions, which constitute an integral part of the historical and cultural heritage of the peoples of Russia, taking into account the peculiarities of their structuring and functioning on the territory of the Russian Federation" [2].

This material played a positive role in terms of legal elaboration and correct terminological fixation, the formulation of the main positions of interaction, social partnership of the state and denominations in the spiritual and moral education of schoolchildren. Such positions were recorded as the participation of a denomination in "addressing issues of ensuring the rights of citizens to free and voluntary introduction of their children to the values and traditions of denominational culture in state and municipal educational institutions, taking into account the legitimate interests and rights of representatives of other religious organizations and the non-religious part of society"; in solving organizational issues related to the teaching of these subjects, the development of their educational and methodological support and scientific and pedagogical base, training, professional development and "receiving recommendations by teachers who want to teach these subjects", conducting an examination of the content of textbooks and educational materials intended for teaching these academic subjects.

In the future, these positions were reflected in the regulatory documents and methodological materials on the FRCSE. Let us note that the "Model agreement on cooperation between the educational administration of a constituent entity of the Russian Federation and a centralized religious organization ..." was developed in 2007 [8].

Since 2009, the participation of denominations in the spiritual and moral education of schoolchildren has been regulated by documents and materials on the FRCSE of federal authorities, including the Ministry of Education and Science of Russia, and since 2012 the Law "On Education in the Russian Federation" [2].

Among the main spheres of participation or functions of denominations, three main ones can be distinguished: participation in determining the content of education in religious culture; participation in the development of appropriate educational and methodological support and in the training of teachers in religious culture, including the development and implementation of professional educational programs. 
Since 2012, the main functions of denominations in the spiritual and moral education of schoolchildren have been enshrined, as indicated, in Article 87 of the Law "On Education in the Russian Federation" [2]. This is the norm (part 3 on examination) in centralized religious organizations of exemplary basic educational programs of academic subjects, courses, disciplines (modules) aimed at obtaining by students' knowledge about the basics of the spiritual and moral culture of the peoples of the Russian Federation, about moral principles, about historical and cultural traditions of the world religion (world religions). The subject of the examination is compliance with the " spiritual doctrine, historical and cultural traditions of this organization."

Such an examination actually means coordination of the content of education in religious cultures with the relevant religious organizations. Based on this content, educational and methodological support is then developed, and teaching staff is trained. The procedure for conducting a confessional examination of exemplary basic educational programs is set out in the methodological materials of the Ministry of Education and Science of Russia on this issue [8 p.17].

Taking into account these requirements, the teaching staff of the oldest in the North Caucasus Dagestan State Pedagogical University conducts active educational and scientific and methodological work to form the spiritual and moral qualities of students.

At the faculties of the DSPU lectures are given, practical classes are held on a cycle of socio-humanitarian disciplines: Muslim law, religious studies, history of world religions, ethnology, philosophy of religion, intercultural communication in the educational space, etc. In 2019, on the basis of the Department of Social and Humanitarian Disciplines of the DSPU, to help teachers of educational institutions of the republic, an additional professional advanced training program "Foundations of World Cultures and Secular Ethics" was developed (authors S.G. Hiyasova, M.G. Mustafaeva). This advanced training program was developed in accordance with the requirements of the federal state educational standard for primary general education, the Concept of spiritual and moral development and education of the personality of a citizen of Russia.

Based on the fact that $90 \%$ of the population of the republic professes Islam, 10\% other religions, the program includes various modules on the basics of world religious cultures (Jewish, Orthodox, Islamic, etc.) and is implemented within the framework of the course "Foundations of Religious Cultures and Secular Ethics". It has a culturological character and is quite relevant. Its importance is due to the fact that the nature of a secular school is determined by its relationship with the social environment, religious associations, recognition of freedom of religion and worldview of participants in the educational process.

The purpose of this training course is to prepare teachers of elementary grades, history, law, Russian language and literature to teach a comprehensive training course "Fundamentals of World Religious Cultures and Secular Ethics" (FWRCSE) to form their necessary competencies in the field of teaching the curriculum.

This course will improve the theoretical and practical training for the implementation of FWRCSE through familiarization with the essence of religious culture and secular ethics, the regulatory framework of this subject, requirements for the development of thematic planning and other relevant materials that make it possible to make an adequate choice of technologies and teaching methods of the FWRCSE.

The main principles inherent in the content of the program are community in diversity, multi-unity, multiculturalism that reflect the cultural, social, ethnic, religious complexity of the modern world in general, and Dagestan in particular. Only a highly qualified teacher who has undergone special training can be entrusted with the teaching of lessons on the foundations of world culture and secular ethics. It is important here not only to give stu- 
dents dry facts, but to try to convey to them as much as possible the wisdom, knowledge and moral foundations that humanity has accumulated for millennia. Perhaps these are the lessons that in the future will protect some of the children from rash decisions and direct them to the right path in life.

The current situation in the Republic of Dagestan, associated with the re-Islamization of all spheres of public life, obliges us to reckon with the fact that the religiosity of the republic's population is inextricably linked with the problems of the spiritual revival of a person, and this in its own way specifically takes the form of moral and legal law. As we noted above, in a region where the majority of the population is Muslim, for a certain part of Dagestanis, Sharia to some extent begins to acquire the character of a law of life.

It is interesting to note that in any legal system (the history of law has more than 40 thousand varieties of legal systems, of which about 4 thousand are modern) there are variable and constant components. Comparative study of the types of legal systems, their components (industries, institutions, norms) is the subject of comparative jurisprudence, which has long identified several main legal families, each of which includes many national and religious legal systems.

As evidenced by the studies of well-known Islamic scholars: G.M. Kerimov, L.R. Syukiyainen, M.Z. Misrokov, M.V. Vagabov, Z.M. Abdulagatov and others, Muslim law is one of eight existing today, in the world of legal families. Its study for Russia, including for the Republic of Dagestan, is of particular importance. A feature of Muslim law in the regions where Islam is traditionally spread is that the principles and norms of Sharia are especially manifested in family and domestic relations [6.p.130].

Islam is based on ideology that shapes the worldview and life aspirations of its followers. It is followed by religious precepts that determine the way of life of Muslims, and are also the source of his moral and ethical code. In third place are legal norms. These three interacting elements form a harmonious mechanism for regulating family and household relations of the peoples of Dagestan.

With the aim that the students of the Faculty of Management and Law of the DSPU could professionally analyze the problems of Muslim law as a socio-cultural phenomenon at the faculty for more than 15 years, an elective course "Fundamentals of Muslim Law" (compiled by M.B. Mustafaev, M.G. Mustafaeva, F.M. Mustafaev), which takes into account the historical and ethno-confessional specifics of the region and the processes of Islamic revival in the post-Soviet space. The role and importance of teaching this special course is steadily increasing, and the students of the faculty show great interest. On the subject of this special course, graduation theses are written and successfully controlled, in which the most pressing problems of the theory and practice of Muslim law are considered.

In the process of teaching the basics of Islamic law at the faculty, we do not equate Sharia with Islamic law. In fact, Shariah covers a wider range of issues: both secular and religious ones. In it, they are presented as a single system of laws regulating economic life, moral and ethical norms, Muslim rituals and holidays that determine the behavior of believers and the order of life of the entire Muslim community. The Shariah sets out in detail the prohibitions, lists the permissible and condemned actions [4, p. 36]. As noted by the well-known expert on Muslim law L.R. Syukiyainen "Shariah is a universal, the widest possible complex norm, the main distinction between which is along the line of religious and cult precepts (ibadat) and the rules of worldly relationships between people (muamalat) [6, p. 117]. Sharia subordinates to itself all the phenomena of human life, penetrates into its most delicate and intimate corners. And Muslim law (fiqh) is an integral part of the Sharia [9, p. 98]. 
Almost all faculties of a pedagogical university conduct disciplines as religious studies, history of world religions (faculty of Human resources, history, graphic arts, etc.) In our opinion, training students in this direction is necessary for a modern specialist. It is known that the problems of religion with all its types and forms are the traditional content of all philosophical systems. Philosophy not only explored various religious beliefs, but even formed its own specialty, i.e. the philosophy of religion. The study of religion inevitably turns us to philosophical and worldview questions about man, about the world, and society.

University students study with interest the peculiarities of the religions of Dagestan taking into account the specifics of the republic, as a multinational and polydenominational region of the Russian Federation. All religious denominations (Islam, Orthodoxy, Judaism, etc.) coexist tolerantly on the territory of the mountainous republic.

It should be especially noted that in recent years among DPU students there has been a noticeable increase in interest in Islam, Muslim law, and religious disciplines in general. At the same time, it must be admitted that such interest is explained not only and not so much by the recognition of the serious contribution of Muslim lawyers to the world legal culture, but by the role that Islam plays in the modern world, which has a direct impact on the political situation in many countries and the system of international relations in general. Therefore, in the process of teaching special courses, we especially draw the attention of students to the fact that it would be a serious mistake to unconditionally associate Islam and Sharia only with politics. After all, Islam is, first of all, a world religion and a corresponding culture that underlies the way of life of many generations of followers of Islam. The most important part of this culture is Sharia, which occupies a special place in Islam. It is in the Sharia that the universal character of Islam is clearly manifested.

Sharia is a very controversial phenomenon, a kind of meeting point for religion, morality, and law. When they say that Islam is both a faith and a way of life, then such a synthesis is embodied precisely in the Shariah. It is safe to say that within the framework of those complex processes of the search for truth, perhaps, the Sharia can play in Dagestan society the role of a constant uniting Muslims, a common guideline for all of them, and even a guarantor of the inviolability of Islam as a civilization [9, p.13].

In this regard, it should be noted the work of $Z$. Abdulagatov "Islam in the mass consciousness of Dagestanis" (Makhachkala, 2008), where the author considers the problems of adaptation of the mass Islamic consciousness to the conditions of global changes and on this basis the search for the priorities of the moral guidelines of today's Dagestani Muslim is carried out. In terms of the formation and definition of the morality of the Dagestanis, he put forward the following questions:

1. Can religious morality be the universal basis of morality in a society that has declared the pluralism of worldviews and ideologies?

2. To what extent does the mass consciousness of Dagestanis recognize a person's religiosity as a necessary condition for morality?

3. Is an ordinary Muslim inclined to adhere to strict religious morality contained in the fundamental sacred texts or, in the context of globalization and other processes and changes, will he look for other ways of adapting to the changing world? [1, p.131]

Analyzing the results of questionnaires of university students of the republic, the authors come to the conclusion that the principles of faith, voluntarily chosen by a person, express the autonomy and subjectivity of his morality. But religion cannot recognize the autonomy of morality in the sense of the possibility of being moral outside of it. Often, students argue that only a connection with God makes a person a chosen spiritual being. At the same time, they very often refer to the well-known statement of F.M. Dostoevsky: "If 
there is no God, then everything is allowed." The same statement of the great Russian writer is given in the "Fundamentals of the social program of Russian Muslims" [6, p. 18]. According to the results of opinion polls conducted by Z.M. Abdulagatov, Sharia is assigned a role mainly as a regulator of interpersonal relations in the family, in the sphere of morality, but its significance in the formation of morality is not absolutized by the overwhelming majority of Dagestanis. Some believers deny the universal and absolute nature of religious morality, the exclusive right of religion to form a moral personality $[1, p .76]$.

\section{Лumepamypa}

1. Абдулагатов 3.М. Ислам в массовом сознании дагестанцев. Махачкала, 2008

2. Закон «Об образовании в Российской Федерации». М., 2012.

3. Метлик И.Б. «Социальное партнерство государства и конфессий в духовнонравственном образовании школьников» // Педагогика. №7, 2015.

4. Мустафраева М.Г., Хиясова С.Г., Мустафраев Ф.М. Этико-нравственные ценности ислама в образовании и воспитании молодежи: Учебное пособие. Махачкала, 2018.

5. Мустафраев М.Б., Мустафраева М.Г., Мустафраев Ф.М. Основы мусульманского права: Учебное пособие. Махачкала, 2009.

6. Предварительные результаты мониторинга...в регионах Российской Федерации.24.04.2007. На сайте общественной палаты РФ http//www/opf.ru

7. Письмо Минобрнауки России от13 июля 2007 г.№03-1584.

8. Письмо Минобрнауки России «О преподавании учебных предметов по истории и культуре религий в школе» от 25 ноября 2009 г. №03-831.

9. Сюкияйнен Л.Р. Мусульманское право. М.: Главная редакция Восточной литературы, 1986.

10. Хиясова С.Г., Мустафраева.М.Г., Мустафраева 3.С. Перспективы учебного курса «Основы религиозной культуры и светской этики в контексте новой образовательной парадигмы» // Экономические и гуманитарные исследования регионов. Ростов/н Дону, 2018. №2.

11. Хиясова С.Г., Мустафраева М.Г., Мустафраеев Ф.М. Проблемы преподавания религиоведения в вузе (вопросы статуса, структуры и методологии) // Экономические и гуманитарные исследования регионов. Ростов/н Дону. 2018. № 3.

12. Maida G. Mustafaeva, Elmira Sh. Musaeva, Zarema S. Mustafaeva. Various Problems of Educational Process In Multilingual Dagestan Under the Globalization Conditions: History And Modernity // Научный альманах стран Причерноморья.

2018. № 1 (13). C. 11-18.

\section{References}

1. Abdulagatov Z.M. Islam $\mathrm{v}$ massovom soznanii dagestantsev [Islam in the mass consciousness of Dagestanis]. Makhachkala, 2008 (in Russian).

2. Zakon «Ob obrazovanii v Rossiyskoy Federatsii» [Law "On Education in the Russian Federation"]. Moscow, 2012 (in Russian).

3. Metlik I.B. «Sotsialnoye partnerstvo gosudarstva i konfessiy v dukhovnonravstvennom obrazovanii shkolnikov» ["Social partnership of the state and denominations in the spiritual and moral education of schoolchildren"]. Pedagogika. No.7, 2015 (in Russian). 
4. Mustafayeva M.G., Khiyasova S.G., Mustafayev F.M. Etiko-nravstvennyye tsennosti islama v obrazovanii i vospitanii molodezhi: Uchebnoye posobiye [Ethical and moral values of Islam in the education and upbringing of youth: Textbook]. Makhachkala, 2018 (in Russian).

5. Mustafayev M.B., Mustafayeva M.G., Mustafayev F.M. Osnovy musulmanskogo prava: Uchebnoye posobiye [Fundamentals of Islamic Law: Textbook]. Makhachkala, 2009 (in Russian).

6. Predvaritelnyye rezultaty monitoringa...v regionakh Rossiyskoy Federatsii 24.04.2007. Na sayte obshchestvennoy palaty RF [Preliminary results of monitoring $\ldots$ in the regions of the Russian Federation. 24.04.2007. On the website of the Public Chamber of the Russian Federation]. Available at: http//www/opf.ru (in Russian).

7. Pismo Minobrnauki Rossii ot13 iyulya $2007 \mathrm{~g}$. [Letter of the Ministry of Education and Science of Russia dated July 13, 2007]. No. 03-1584 (in Russian).

8. Pismo Minobrnauki Rossii «O prepodavanii uchebnykh predmetov po istorii i kulture religiy v shkole» ot 25 noyabrya 2009 g. [Letter of the Ministry of Education and Science of the Russian Federation "On the teaching of academic subjects on the history and culture of religions at school" dated November 25, 2009]. No. 03-831 (in Russian).

9. Syukiyaynen L.R. Musulmanskoye parvo [Muslim law]. Moscow: Glavnaya redaktsiya Vostochnoy literatury, 1986 (in Russian).

10. Khiyasova S.G., Mustafayeva.M.G., Mustafayeva Z.S. Perspektivy uchebnogo kursa «Osnovy religioznoy kultury i svetskoy etiki v kontekste novoy obrazovatelnoy paradigmy» [Prospects for the training course "Fundamentals of Religious Culture and Secular Ethics in the Context of a New Educational Paradigm." Economic and humanitarian studies of regions]. Ekonomicheskiye i gumanitarnyye issledovaniya regionov. Rostov-on-Don, 2018. No. 2 (in Russian).

11. Khiyasova S.G., Mustafayeva M.G., Mustafayeev F.M. Problemy prepodavaniya religiovedeniya v vuze (voprosy statusa, struktury i metodologii). Ekonomicheskiye i gumanitarnyye issledovaniya regionov [Problems of teaching religious studies at the university (questions of status, structure and methodology). Economic and humanitarian studies of regions]. Rostov-on-Don. 2018. No. 3 (in Russian).

12. Maida G. Mustafaeva, Elmira Sh. Musaeva, Zarema S. Mustafaeva. Various Problems of Educational Process in Multilingual Dagestan Under the Globalization Conditions: History and Modernity. Science Almanac of Black Sea Region Countries. 2018. No. 1 (13). pp. 11-18. 